\title{
Manufacturing supply chain operation process modeling based on cloud
}

\author{
Liguo $\mathrm{YaO}^{\mathrm{a}}{ }^{\text {,Haisong Huang }}{ }^{\mathrm{b}}$ \\ (Key laboratory of Advanced Manufacturing Technology of Ministry of Education, Guizhou \\ university, Guiyang 550025, CHN) \\ ayaoliguo1990@163.com, bhuang_h_s@126.com
}

Keywords: cloud platform; manufacturing supply chain; supply chain management; supply chain

\begin{abstract}
In order to solve the problems existing in the existing manufacturing supply chain operational efficiency is low, the difficulty of coordination management and maintenance difficulties, analyzes the operating status of manufacturing supply chain, the cloud technology used in traditional manufacturing supply chain, a manufacturing supply chain cloud platform innovation model is proposed. The manufacturing supply chain cloud platform management system architecture can effectively improve the efficiency and quality of manufacturing supply chain services.
\end{abstract}

\section{Introduction}

The core idea of cloud computing is the formation of an abstract, general, highly virtualization and dynamic expansion of the resource pool, to disperse the grid, servers, storage, applications, service resources aggregation, integrated into the "cloud" unified storage and enterprise households or individuals through the network according to the need to pay at any time to obtain the computing services. [1-2]

In the information era, with the development of economic integration and the globalization of supply chain, advanced cloud computing technology for the transformation and upgrading of traditional industries provides new ideas, in improving the efficiency of traditional manufacturing operations at the same time also bring economic benefits. Due to economies of scale and high reliability of cloud computing, support rapid deployment, achieve high efficiency and low advantage [3], has been manufacturing favored, such as the United States to build the world's largest manufacturing industry $\mathrm{B} 2 \mathrm{~B}$ online trading platform of $\mathrm{mfg}, \mathrm{Gu}[6]$ to Ningbo mold manufacturing as the application background of the development of the mold industry cloud manufacturing service platform.

\section{Current situation of manufacturing industry supply chain}

\subsection{Manufacturing supply chain system research and development, maintenance difficulties}

After decades of standardization work and our country manufacturing industry standard system is improved and perfected, but it still has some problems, such as the current our country horizontal lathes - Testing of the accuracy still perform in 1997 to develop national standards. In addition, manufacturing supply chain as a typical discrete manufacturing supply chain, to meet the needs of procurement, finance, logistics, sales and upstream and downstream suppliers. Therefore, ordinary software vendors without knowing the rules of the industry under the premise, difficult to R \& D, design and maintenance in line with the requirements of the software, and systems of enterprises for independent R \& D products may too personalized no uniform standards.

\subsection{The lack of participation in the supply chain of small and medium enterprises}

Since the reform and development, the number of manufacturing enterprises in China has gradually increased. But in addition to the Shenyang Machine Tool Co., Ltd. and Changchun First Automobile Factory established businesses, the vast most newcomer manufacturing enterprises are small and medium enterprises, operation of the lack of funds, lack of equipment resources, personnel quality uneven. Therefore, in the face of economic globalization manufacturing supply chain development, small and medium-sized manufacturing enterprises generally feel weak, lack of participation in the enthusiasm. 
2.3 Supply chain in the manufacturing industry, the application of more, less external application

The network of raw material suppliers, manufacturers, distributors, wholesalers and end customers which are connected with the enterprise is called the external supply chain of enterprises. At present, a lot of large manufacturing enterprises hinder on external supply chain related enterprises and management complex, at the same time that the manufacturing industry mainly parts, resulting in most of its manufacturing industry supply chain application in enterprise interior design, purchasing, manufacturing, sales and other departments, is seldom used to achieve between the upstream and downstream of the collaborative management.

2.4 Difficult to adjust the synergy degree of manufacturing supply chain in manufacturing industry.

Manufacturing industry supply chain from manufacturing enterprises and encompasses the constitution of the its raw material supply, transportation and other different enterprises, the various enterprises has a different working methods and management methods and often for knowledge sharing, income distribution, the credibility problem and supply chain members innovation risk caused by internal contradiction to collaboration, such as fake raw materials suppliers, manufacturers and treatment process such as Jerry, causing great losses to the collaborative enterprise. As a result, enterprise collaboration has become an important problem in the supply chain management of manufacturing industry.

\section{Cloud computing machine tool supply chain innovation}

\begin{tabular}{|c|c|c|c|c|c|c|c|c|}
\hline \multirow[b]{2}{*}{$\begin{array}{c}\text { PaaS } \\
\text { Management } \\
\end{array}$} & $\begin{array}{l}\text { Cloud service } \\
\text { management }\end{array}$ & \multicolumn{2}{|c|}{$\begin{array}{c}\text { Account } \\
\text { managemen }\end{array}$} & \multicolumn{3}{|c|}{$\begin{array}{l}\text { Service level } \\
\text { management }\end{array}$} & \multicolumn{2}{|c|}{$\begin{array}{c}\text { Service strategy } \\
\text { management }\end{array}$} \\
\hline & \multicolumn{2}{|c|}{$\begin{array}{c}\text { Incident and problem } \\
\text { management }\end{array}$} & \multicolumn{2}{|c|}{$\begin{array}{l}\text { Monitoring } \\
\text { and order }\end{array}$} & \multicolumn{3}{|c|}{$\begin{array}{c}\text { Resource } \\
\text { control }\end{array}$} & $\begin{array}{l}\text { Service } \\
\text { supply }\end{array}$ \\
\hline & \multicolumn{3}{|c|}{$\begin{array}{c}\text { Platform and Virtualization } \\
\text { Management }\end{array}$} & \multicolumn{2}{|c|}{$\begin{array}{l}\text { Service } \\
\text { directory }\end{array}$} & \multicolumn{3}{|c|}{$\begin{array}{c}\text { Service automation } \\
\text { management }\end{array}$} \\
\hline & $\begin{array}{l}\text { Cloud service } \\
\text { management }\end{array}$ & $\begin{array}{r}\mathrm{Ac} \\
\mathrm{man}\end{array}$ & $\begin{array}{l}\text { sunt } \\
\text { semer }\end{array}$ & \multicolumn{3}{|c|}{$\begin{array}{l}\text { Service level } \\
\text { management }\end{array}$} & \multicolumn{2}{|c|}{$\begin{array}{c}\text { Service strategy } \\
\text { management }\end{array}$} \\
\hline & \multicolumn{2}{|c|}{$\begin{array}{c}\text { Incident and problem } \\
\text { management }\end{array}$} & \multicolumn{2}{|c|}{$\begin{array}{l}\text { Monitoring } \\
\text { and order }\end{array}$} & \multicolumn{3}{|c|}{$\begin{array}{c}\text { Resource } \\
\text { control }\end{array}$} & $\begin{array}{l}\text { Service } \\
\text { supply }\end{array}$ \\
\hline \multirow{2}{*}{$\begin{array}{c}\text { IaaS } \\
\text { Management } \\
\end{array}$} & \multicolumn{3}{|c|}{$\begin{array}{c}\text { Platform and Virtualization } \\
\text { Management }\end{array}$} & \multicolumn{2}{|c|}{$\begin{array}{c}\text { Service } \\
\text { directory }\end{array}$} & \multicolumn{3}{|c|}{$\begin{array}{c}\text { Service automation } \\
\text { management }\end{array}$} \\
\hline & $\begin{array}{l}\text { Physical } \\
\text { resource }\end{array}$ & $\begin{array}{r}\text { Servic } \\
\text { integrati }\end{array}$ & & $\begin{array}{l}\text { onitor } \\
\text { tegrat } \\
\text { tegrat }\end{array}$ & & & an & $\begin{array}{l}\text { bstraction } \\
\text { ntrol }\end{array}$ \\
\hline
\end{tabular}

Fig.1 Paas and Iaas management

Cloud computing [1、2] is a new computing model based on the Internet, which is the extension and development of distributed computing, parallel computing, utility computing and grid computing. Through the process of cloud computing for different levels of classification, as shown in Figure 3 can be divided into the following 1:

1、 Iaas(Infrastructure as a Service): users through the rental of Internet data centers, infrastructure and other resources to solve their own hardware needs.

2、Paas(Platform as a Service): users through the rental infrastructure, you can build different information base to solve their own needs.

3、 SaaS(Software as a Service): users through the lease of specific functions of APP, PC applications and other software resources to address their own needs.

\section{Manufacturing supply chain applications}

The upgrading of manufacturing industry makes the competition and survival of all kinds of enterprises become more and more fierce. Good supply chain management can optimize the operation of supply chain, and get the best products and the best profits. So the manufacturing enterprises in the supply chain to seek new change, in this context, design the manufacturing cloud management platform architecture, as shown in Figure 3, is a layer of cloud services, cloud monitoring layer, cloud security layer and the cloud management layer. 


Manufacturing cloud management platform
architecture

Fig.3 Manufacturing cloud management platform architecture

(1) Cloud services layer

According to the different needs of customers and manufacturing enterprises, the cloud service layer is divided into product catalog, account management, order management, service level management, cost management, service generation, receipt management and delivery management. Transfer and acquisition of information through human computer interaction interface.

(2) Cloud monitoring layer

Cloud monitoring layer is divided into business activity monitoring, operation monitoring, application monitoring, middleware monitoring, database monitoring, hard disk monitoring, network monitoring and CPU monitoring. By monitor the operation status of different kinds of software and hardware. All systems work together to ensure the normal operation and maintenance of cloud management platform.

(3) Cloud security layer

Cloud security layer is an important part of the entire management system. Be responsible for data security, operation security and operation security of cloud management platform. There are security authentication, identity management, authorization management, security policy management, encryption management, decryption management, connection management and security integration.

(4) Cloud management layer

Cloud management is the core of the entire management system. Be responsible for all business operations and management of the entire management system. Service strategy, management, monitor and report on, the cloud service management, service level management, service integration, monitor and control generated, time and management and security problems generated.

\section{Conclusion}

Cloud technology provides new manufacturing ideas and methods for manufacturing. In this paper, the combination of cloud technology and traditional manufacturing supply chain, the supply chain of manufacturing supply chain model and cloud management platform architecture Manufacturing. In the manufacturing industry information technology and Internet technology support, through the cloud of the supply chain platform, the use of cloud technology for manufacturing and management of manufacturing products and maintenance. Is conducive to resolving the manufacturing industry supply chain system development, maintenance difficulties, lack of small and medium enterprises to participate in the supply chain, supply chain in manufacturing industry application more, less external application, manufacturing industry supply chain enterprise synergy degree is difficult to regulate, and adjust the industry structure distribution, improve the informatization level of manufacturing industry, improve the traditional manufacturing industry manufacturing, operations 
and sales model.

\section{Acknowledgements}

The research work presented in this paper is supported by Guizhou University Graduate Innovation Foundation (YLG 2016025).

\section{References}

[1] Behrens M, Carlson M, Edmonds A, et al. Open Cloud Computing Interface Infrastructure[M]// OGF Document Series. 2011.

[2] Hayes B. Cloud computing[J]. Communications of the Acm, 2008, 51(7):9-11.

[3] Liu sen. Value Creation of Cloud Computing: An Empirical Study[D], Zhejiang University, 2014.

[4] Gu Xin-jian, Huang Shen-quan. Cloud manufacturing service platform driven by mold manufacturing industry demand.[J].Computer integrated manufacturing systems, 2012,23(1): 1650-1657. 